\title{
Amplifying the voices of young consumers in food advertising research
}

\section{Introduction}

This chapter examines the ethics and practicalities of conducting research with young consumers in a food advertising context. To do this, the chapter draws upon a longitudinal research study conducted with English and Swedish consumers, who at the beginning were aged 12, at the end aged 14. The orienting frame of reference was that of social marketing, a prime directive of which is a client orientation; the seeking of a well-grounded understanding of people and their behaviour in order to encourage behavioural change (Hastings and Domegan, 2014). The primary aim of this research study was to ascertain the characteristics of a creative advertising strategy for healthy eating likely to resonate with the age group. This was achieved by conducting research from the perspective of the young consumers themselves.

The chapter will review a number of aspects of relevance. The rationale for the research study will be addressed. This will be followed by a discussion of the role of the young consumers in the research process, after which fundamental aspects associated with ensuring the ethicality of the research are reviewed. The research methodology adopted will then be explained, followed by detailed descriptions of the research methods and data analysis. Here the emphasis will be on demonstrating how the research study was designed in order to give voice to the young consumers. Finally, an evaluation of conducting longitudinal research with a young research population is provided.

The term young consumers will be used to denote the research population. Where the discussion refers to aspects of childhood more generally (rather than consumer behaviour specifically), children will be used.

\section{Rationale for the research}

The United Nations Convention on the Rights of the Child states as a fundamental right of children the right to the enjoyment of the highest attainable standard of health. Children are also entitled to high standards of research about their lives, which gives due consideration to their views (UNICEF, 1989). Some 25 years after the introduction of the United Nations Convention on the Rights of the Child, the State of the World's Children report (UNICEF, 2014) calls for innovative approaches for addressing problems affecting children and highlights that the most insightful propositions often emerge from children themselves.

This research study responded to a recommendation for a re-orientation of food advertising research to address how advertising may be used to encourage the adoption of healthier diets (Cairns et al., 2013). The research was prompted by the urgent issue of childhood obesity, described by the World Health Organization (WHO) as having reached "alarming proportions" in many countries, posing an "urgent and serious challenge" (WHO, 2016, p. 8). One striking characteristic of the childhood obesity debate is that the voices of the main stakeholder group - children - rarely 
feature. Hence, this research study sought input from young consumers with the aim of representing their voices through a range of fieldwork activities.

\section{The role and status of the young consumers in the research process}

This research study was guided by social constructionism, a research philosophy that holds that our sense of meaning and reality is discursively constructed through language (Hackley, 1998). The consumer remains an autonomous individual, but one whose development of individuality and subjectivity, as well as behaviour, depends upon social interaction. Social constructionism frames research from the perspective of the consumer, rather than the researcher (Hackley, 2001). In the context of childhood obesity this takes on particular prominence, where young consumers' voices need amplifying, with their views of direct relevance to policy makers, food producers and advertisers (Metha et al., 2010). Sparrman (2009, p. 299) recognises the contrasting views of children as 'naïve' versus 'competent' research participants (see figure 1).

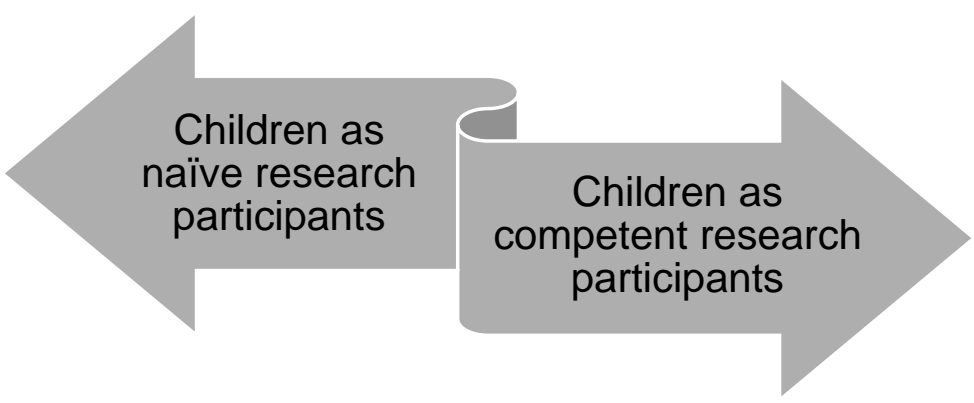

Figure 1: Contrasting views of children as research participants (Sparrman, 2009).

The perception of children as innocent/naïve and in need of protection emanates from developmental psychology and developmental stages. Accordingly, Roedder John (1999) proposes that children proceed through three sequential stages associated with their development as consumers and that each stage involves significant cognitive shifts from pre-school to adolescence - perceptual stage (3-7 years); analytical stage (7-11 years) and reflective stage (11-16 years). By early adolescence, their skills set includes reflective thinking. Improved reasoning skills are accompanied by more complex marketplace knowledge as well as heightened social awareness, including the ability to recognise the perspectives of others.

The notion of the competent child is based upon a socially and culturally constructed child, perceived as an agentive social citizen (Prout and James, 1997; James et al., 1998; Christensen and Prout, 2005). The model of the Social Child (James et al., 1998) sees children as adopting the role of social actors in their own lives, making meaning through interacting with other children and adults alike. This research study positioned the participants as "social actors within the study context" (Davis, 2010, p. 62). This 
focus upon children's lived experience has been facilitated by the theoretical move of social constructionism and assisted by the introduction of the United Nations Convention on the Rights of the Child (Christensen and Prout, 2005; Kellett, 2010). Accordingly, children are provided with conceptual autonomy, regarded as the direct and primary unit of study. Westcott and Littleton (2005) maintain that explicit consideration of the notions of competence and power is required. James et al. (1998) describe children's competencies as different, not inferior to adults. Kellett (2014) recognises that the Convention on the Rights of the Child has resulted in a transfer of power as manifest in research epistemology. It follows that children are gaining the status of "co-creators of knowledge" (p. 24). Within their own subculture of childhood, children enjoy an insider-perspective, investing them with power in their position as gatekeepers to the knowledge therein (Kellett, 2010).

The viewpoint of the young consumers as participating research subjects, in combination with this research study's social constructionist epistemological assumptions, meant that the fieldwork was regarded as a series of events in a coconstructive process of meaning-making (Heath et al., 2009; Bucknall, 2014; Fraser et al., 2014). It was thought that participatory research (as opposed to data gathering) would assist the process of knowledge production (Kellett, 2010). Figure 2 synthesises the discussion in terms of the young consumers' role and status in this research study.

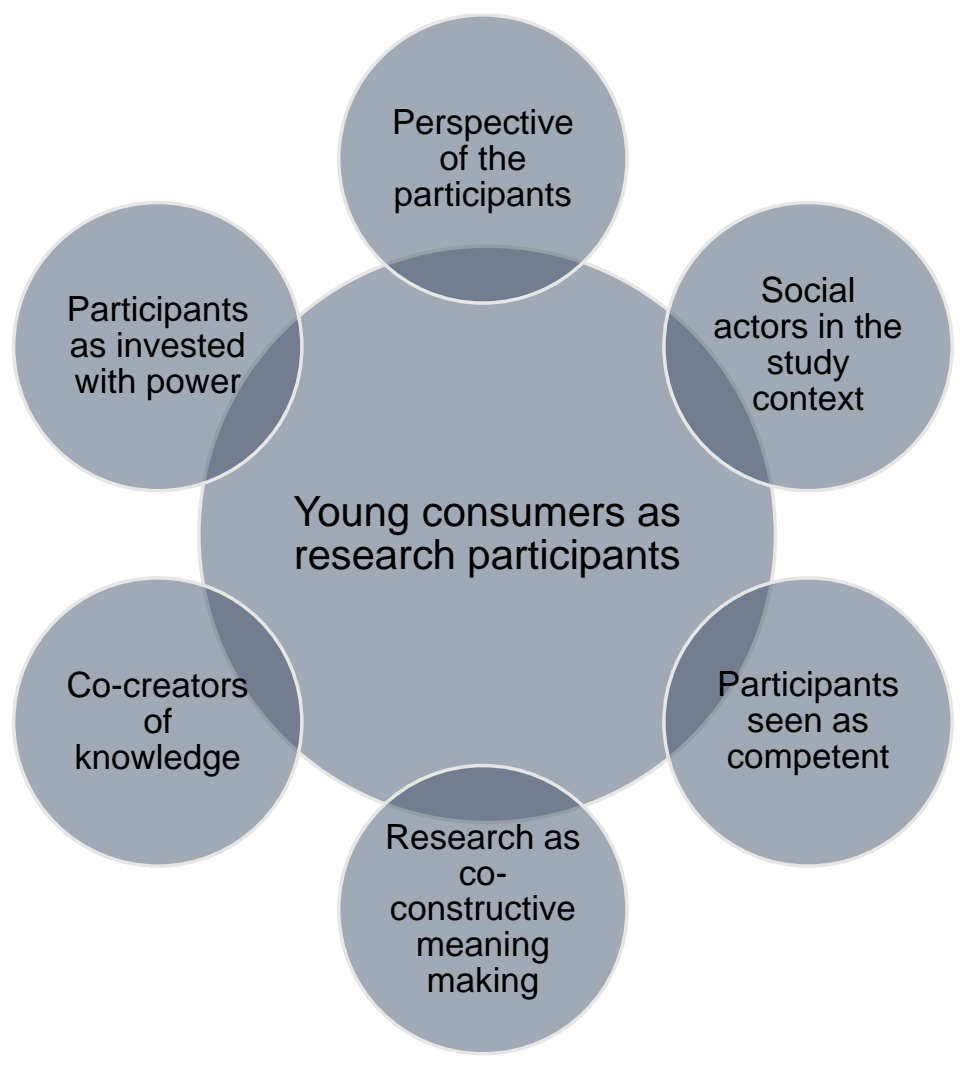

Figure 2: The young consumers' role and status in the research process. 


\section{Ensuring the ethicality of the research study}

The researcher's duty of care to deliver high-quality research as prescribed by the United Nations Convention of the Rights of the Child (UNICEF, 1989), has been noted already. Accordingly, this research study adopted the perspective of the young consumers with the aim to amplify their voices. Young participants' well-being and safety during the research needs to be ensured. Figure 3 depicts the various research guidelines of relevance to this and similar research.

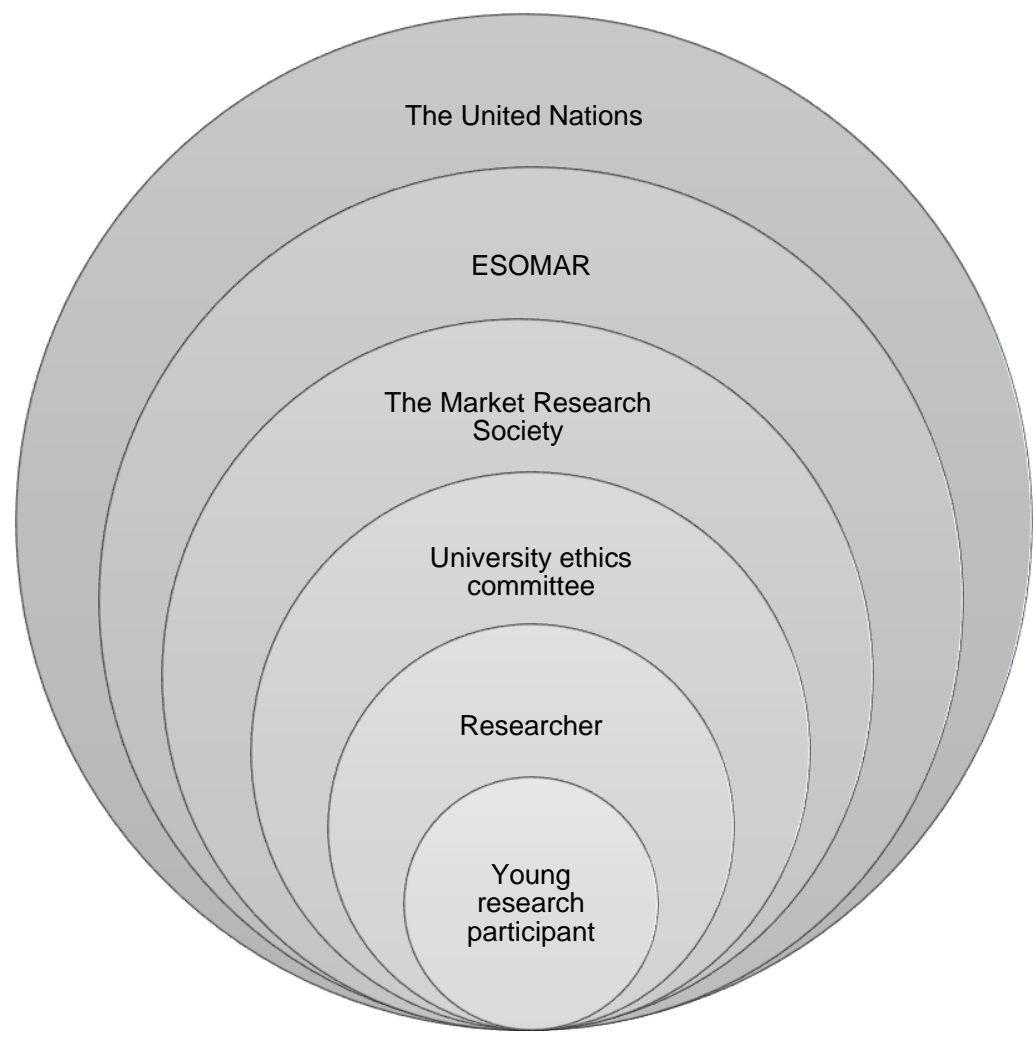

Figure 3: Protective layers safeguarding young research participants.

ESOMAR (World Association of Opinion and Marketing Research Professionals; formerly, European Society for Opinion and Marketing Research) describes itself as an organisation the aim of which is to encourage, advance and elevate market research worldwide (ESOMAR, 2016). The ICC/ESOMAR Code on Market and Social Research was developed jointly with the International Chamber of Commerce (ICC) and contains a Guideline (ESOMAR, 1999) on conducting research with children. In addition to outlining more specific detail on special care and precautions during the research process, the Guideline recognises children's welfare as the overriding priority. The Market Research Society, the world's largest market research association, supports research for commercial purposes and public policy (Market Research Society, 2016). The Market Research Society Code of Conduct (Market Research Society, 2014) requires the permission of a responsible adult for a child to 
participate in research. Before research affiliated with a university can commence, it needs approval by the ethics committee of that institution. Furthermore, in the United Kingdom, researchers require a DBS certificate (Disclosure and Barring Service, no date) to conduct research with children.

Obtaining informed consent represents a critical stage in the research process and amounts to potential participants being fully briefed via an information sheet about the nature of the research and how the findings may be used (Hill, 2005; Heath et al., 2009; Alderson, 2014). This research study used different information sheets for parents and young consumers, the latter of which used simple language to ensure understanding. The notion of gaining informed consent recognises children's agency (c.f. the competent child [Prout and James, 1997]), in terms of their competency to engage with research and ability to decide whether to take part (Heath et al., 2009). The Market Research Society Code of Conduct (Market Research Society, 2014) stipulates their entitlement to decline, even if a parent has granted permission. Furthermore, the right to withdraw at any stage should be respected. Being longitudinal, this research study re-negotiated consent for each stage, commensurate with the requirement for "ongoing consent" (Kellett, 2010, p. 25). It recognised the entitlement to anonymity; protection of the specific identities of research participants (Heath et al., 2009).

The fieldwork was conducted in a school environment. Schools as research sites may attract criticism based upon potential existence of a power relationship created by teacher-pupil authority. However, many studies involving children tend to recruit through schools, in a bid to satisfy ethics concerns and reflecting ease of access (Banister and Booth, 2005). Importantly, schools enable insight into the participants' behaviour in a social environment (Banister and Booth, 2005), a characteristic commensurate with this research study's social constructionist perspective.

On completion of a study, it is appropriate to share the findings with the participants. Heath et al. (2009) maintain a large volume of research with young participants notwithstanding, dissemination targeted specifically at them as a primary audience is uncommon. Recognising the duty of reporting back as part of an ethics contract, this research study shared academic papers written at the completion of a research stage with the participating schools. In terms of dissemination targeted specifically to the participants, a dedicated talk upon completion of all the fieldwork was offered. Figure 4 depicts fundamental ethics requirements met at each stage. 


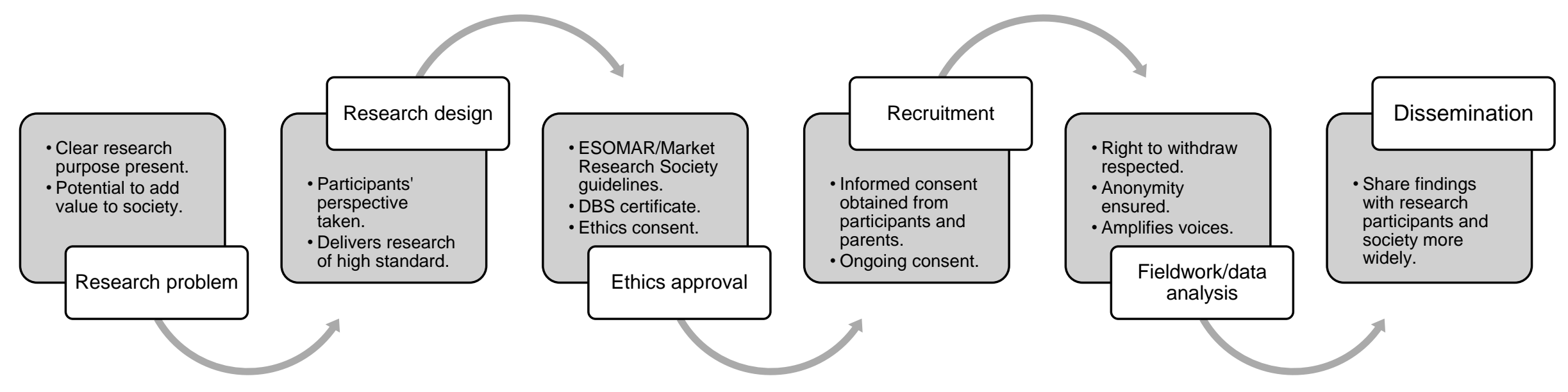

Figure 4: Fundamental ethics considerations for each research study stage. 


\section{Listening to the voices of young consumers}

The following sections will account for the research philosophy underpinning this research study, justifying its interpretivist perspective and outlining its social constructionist assumptions.

\section{Adoption of an interpretivist perspective}

This research study sought qualitative, in-depth understanding of the young consumer group and their discourses around food advertising. It has been proposed that perceptions of healthy eating are specific to the context and the age group of the research participants, making an interpretivist approach with a focus upon understanding and interpretation appropriate (Chan et al., 2009). Further support for interpretivism comes from Pettersson and Fjellström (2006), who maintain that the understanding of food in everyday life and the use of food in social interaction represent culturally specific forms of knowledge. Hackley (2001, p. 49) accounts for interpretivist marketing research as placing the emphasis upon "lived experiences of consumers in engagement with social practices of consumption" and claims that critical, sophisticated and culturally informed scholarship of this nature offers the richest opportunity for social scientific investigation.

Figure 5 offers an overview of the approach adopted by this research study. Accordingly, interpretivist research methodology was employed to explore the meaning co-created by the young consumers in a range of fieldwork activities, which simulated social environments in order to gain access to their lived experiences. This was achieved by conducting all stages of the research using a group context; focus groups for discussions and workshops for the hands-on activities of collage construction and advertisement design. The research was conducted from the perspective of the young consumers, with the spotlight turned upon language. The research design recognised that the participants would benefit from a range of outlets for their opinions and ideas, with the opportunity to express themselves both verbally and visually.

The resulting verbal and visual data were then analysed, providing understanding and interpretation in the form of deep participant-centred insight. Essentially, the empirical research involved listening to, interpreting and, eventually, representing the voices of the young consumers. The longitudinal perspective allowed listening to their voices over time and showed how their discourses around food advertising developed and changed in tandem with their acquisition of more sophisticated market persuasion knowledge. 


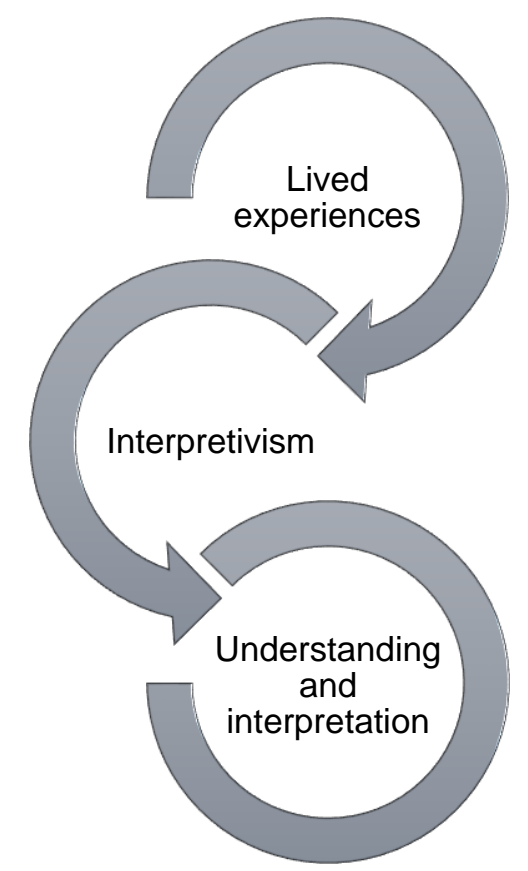

Figure 5: Interpretivist perspective to the study of young consumers and food advertising.

\section{Ontology of social constructionism}

Within the overall interpretivist perspective, the research design was influenced by Hackley's (1998; 2001) ideas on social constructionism. Unlike "mainstream marketing", which tends to promote a scientific research approach concerned with establishing statistical support for empirical truths, social constructionism seeks to reveal a realm of marketing practice as a "complex literary construction", where language plays a central role (Hackley, 2001, p. 2). It follows that meaning is a social construction and that our sense of meaning and reality is discursively constructed through the "constitutive language of the everyday" (Hackley, 1998, p. 21). On a similar note, Berger and Luckmann (1967) contend that the most important vehicles of realitymaintenance are those of language and conversation. De la Ville and Tartas (2010) claim a more comprehensive understanding of children's consumption activities to follow from a focus upon children's everyday language. Similarly, Moisander and Valtonen (2006) maintain that meaning is constructed discursively in social interaction using text, talk, sounds and images as well as signifying practices.

The social constructionist epistemological model of the consumer sees them as selfdirected entities, who actively seek meaning through symbolic engagement with the world (Hackley, 2003). In the realm of food and food consumption, family and friends are the most powerful agents of socialisation, including socialisation for preference and choice of different foods for young consumers (Young, 2003). When it comes to objects of empirical analysis, textual and visual materials provide sites where meanings and forms are accessible to the researcher (Moisander and Valtonen, 2006). Figure 6 depicts the main social constructionist assumptions of relevance to this research study. 


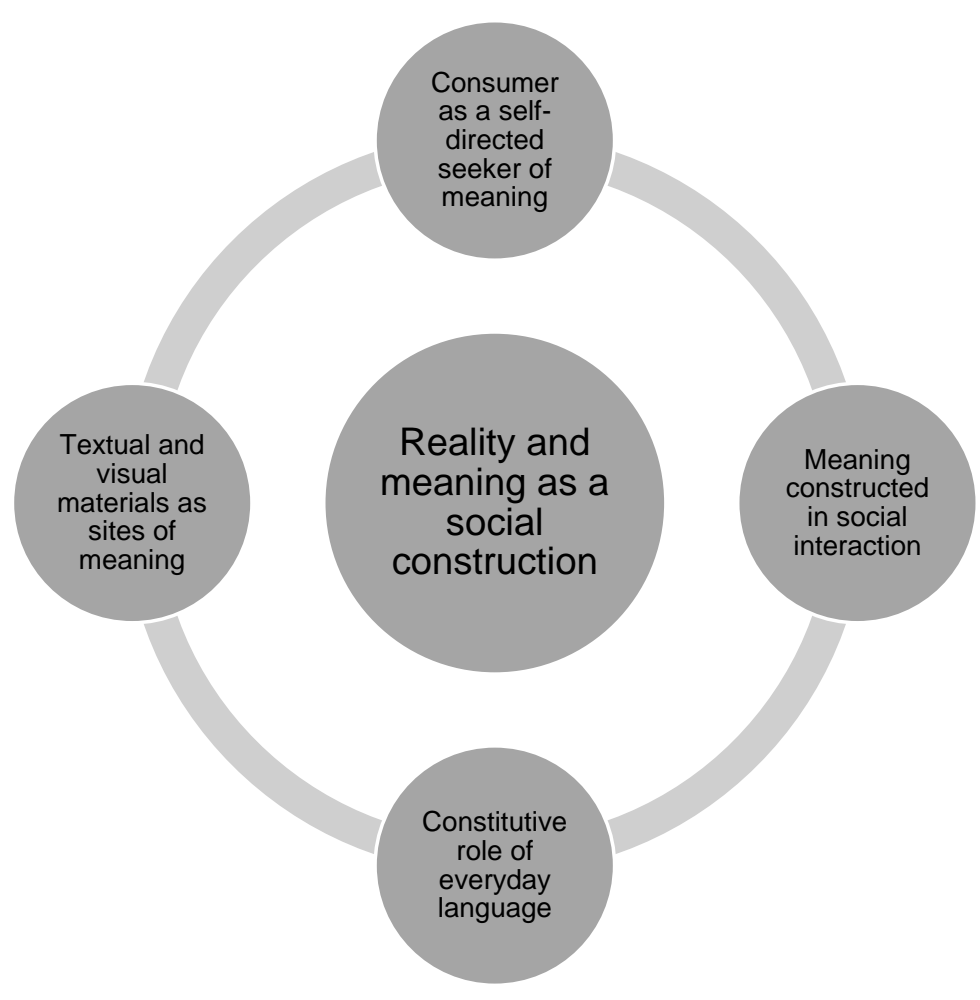

Figure 6: Social constructionist assumptions of relevance to this research study.

\section{Social constructionist perspective on the distributed self}

The second stage of the fieldwork concerned research participants' perception of themselves and amounted to their constructing audience profiles of a 'typical 13-yearold consumer'. The design of this stage was influenced by Wetherell and Maybin's (1996) proposition that the self is socially constructed. This view argues for a merged view of the person and their social context, "where the boundaries of one cannot be easily separated from the boundaries of the other" (p. 222). It follows that the self is continually shaped and re-shaped through interactions with others within a social world by everyday conversations, current social practices and so on. People move across different sites and so find themselves in different social contexts with different identity possibilities. As a consequence, the self may be described as distributed, continually spreading and changing across a relational and social field. It follows that the self is also contextual as well as emergent, due to its fluid and continuously changing format. Wetherell and Maybin claim that language, talk and discourse provide important raw materials for the construction of the self and that our identities are, in part, discursive products. In the course of its use, language constructs the world and the self. Meaning is a joint accomplishment and the self a product of collaborative, provisional and contextual negotiation. 


\section{Stages in the co-constructive process of meaning-making}

Hackley's (2003) ontological assumption that advertising can be seen in a socially constructed light was central to the study, requiring varied and creative research techniques (Hackley, 2001). Seeing young consumers as socially and culturally situated calls for localised, sensitive and flexible research methods (O'Donohoe and Tynan, 1998), which may be achieved by a "child-centric" approach to research within marketing (Banister and Booth, 2005, p. 157) or what Bartholomew and O'Donohue (2005) refer to as the adoption of a "child's eye view" (p. 441). Consequently, this research study sought to embrace the participants' active participation in an array of research techniques. The three research stages will now to be explored in turn.

\section{Stage 1 - exploratory research}

Stage 1 of the research study sought to explore the 12-year-old participants' understanding and perceived importance of the concept of healthy eating. Their role as current food customers with their own spending power and their fulfilment of an influence market with impact upon household food purchases (McNeal, 1992) was also of interest, as was their perceived influence of socialisation agents upon their food choice. Further, insight regarding their perception of food advertising in various media was collected. This stage was regarded as formative, influencing the direction of the following two research stages.

Given the importance of the social context in the realm of food and food consumption (Young, 2003) and the adoption of a social constructionist ontology, it was established that a group context would be appropriate for all three research stages. Hence, focus groups would be used due to their methodological assumption that social knowledge is produced in interaction with others (Smithson, 2000; Tonkiss, 2004). The focus groups were seen as simulating those routine communicative contexts where meaning is socially constructed through everyday talk (Lunt and Livingstone, 1996), essentially providing a "collecting tank" for relevant discourses (Puchta and Potter, 2004, p. 126). The suggestion that focus groups may address any power imbalance between the researcher and young participants, as they allow for the group to be collectively powerful, was another imperative for their use (Smithson, 2000; Hennessy and Heary, 2005).

A focus group is "focused" in that it performs some form of collective activity (Oates, 2000 , p. 186). Each focus group addressed a number of tasks, guided by a semistructured interview guide. The purpose of the session was explained, stressing the absence of correct/incorrect answers. The tasks involved a discussion of print advertisements for healthy/unhealthy food/drinks, followed by an exploration of the meaning of healthy/unhealthy foods. In a card sorting activity, the participants negotiated the order of importance of cards containing images/names of socialisation agents (family, school, peers, shop environment, television advertising, print advertising, the internet, text messaging) in terms of their influence upon their food choice, followed by a discussion of the nature of such influence. After a discussion of food brands' websites, the participants played an advergame on a branded website 
hosted by a breakfast cereal brand. This was followed by a discussion of the purpose of advergames. Preceded by a discussion of their use of YouTube, the participants viewed television advertisements for healthy/unhealthy food/drinks, used to anchor a discussion on television advertising. Finally, the participants filled out an anonymous exit questionnaire collecting data on their television viewing behaviour, internet usage, etc. The groups were audio recorded. Figure 7 provides an overview of the research activities used.

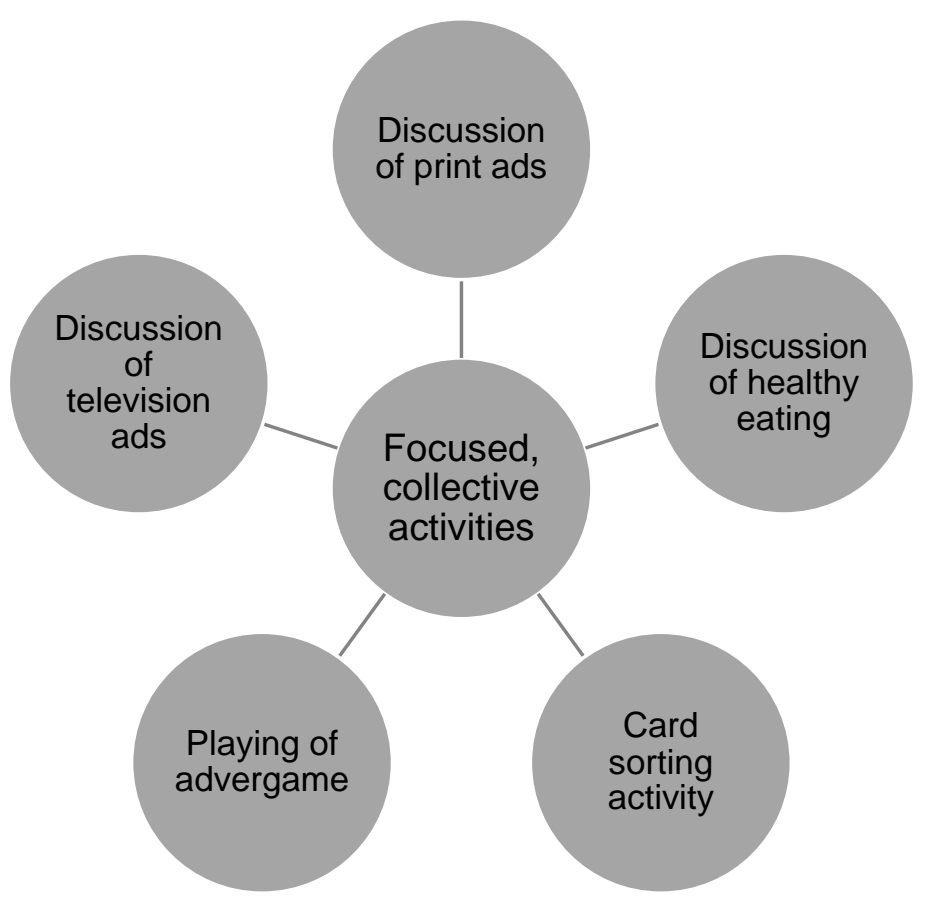

Figure 7: Research activities used within the stage 1 focus groups.

\section{Stage 2 - collage construction}

The following year, when the participants were 13, the research study sought insight into their perception of themselves in terms of their characteristics and what motivates them as consumers. In the spirit of Wetherell and Maybin's (1996) contention that the self is socially constructed, resulting from a collaborative, provisional and contextual negotiation, consumer collages were constructed jointly by groups of participants. The participant-centred approach to visual research (Emmison et al., 2012) described here and for stage 3, allowed for active involvement of the participants. Importantly, in this style of qualitative research visual materials may be used as a tool to decrease the power differential between the researcher and the young participants (Emmison et al., 2012).

Moisander and Valtonen (2006) describe collages as a "product of discursive practice". As such, collages represent "visual language" and can be read as "visual cultural stories" (p. 26). Further, Moisander and Valtonen claim that "collaborative and reflexive use of visuals" (p. 96) provides research participants with increased voice in representing study phenomena, which supported the aim to empower the participants 
and meant that the research was conducted from their perspective. Emmison et al. (2012, pp. 20-21) refer to "participatory visual approaches" as a more "emancipatory style of qualitative research", where participants take on the role of image-makers and may engage in "visual storytelling". For consumer profiling, the technique makes participants' "inner representations of experiences as ideas, imagery, and consumption practices" accessible (Zaltman and Coulter, 1995; Belk et al., 2003; Cherrier, 2012, p. 93; Siemieniako and Kubacki, 2013) and may enhance their engagement (Havlena and Holak, 1996). Siemieniako and Kubacki (2013) claim collages make the social side of the research issue visible. The motives of this research study were similar to those of Siemieniako and Kubacki (2013), namely, ensuring that communications campaigns reflect the reality of the motivations and perceptions of the particular consumer group to deliver more targeted and effective communications (c.f. Havlena and Holak, 1996; Martin and Peters, 2005). The sum of these qualities were in line with this research study's social constructionist ontology.

Each workshop constructed a collage using images and words in order to describe 'a typical 13-year-old consumer' (boy and girl). The participants were instructed to fill a poster sheet with images and words in response to a set of questions delivered verbally and on a worksheet. For instance, the questions prompted consideration of such aspects as the interests and aspirations of these young consumers, as well as their relationship to food brands and attitudes towards such concepts as organic food and Fairtrade. The absence of right and wrong answers was pointed out. Magazines and other suitable materials were made available, as well as scissors, coloured pens and glue sticks. The materials were selected to ensure availability of a wide variety of images suited to the worksheet questions. The workshops were audio recorded.

\section{Stage 3-advertisement evaluation and design of a healthy eating advertisement}

The objective of the final stage was two-fold. It took place a year later and sought the participants' (aged 14) reactions to current television advertisements promoting healthy eating/a healthy lifestyle, in order to identify their dominant discourses in relation to this topic. What is more, the participants devised communication strategies appropriate for advertising healthy eating/foods to their own age group by designing their own advertisements.

For the advertisement evaluation, a similar approach to that used by Chan and Tsang (2011) was employed. Chan and Tsang measured Hong Kong youths' attitudes to television advertisements promoting green lifestyles. Chan and Tsang's interview questions were adapted for use in this research study. The participants watched two television advertisements. After each one, questions were posed and, equipped with tablets, the participants engaged in a discussion on Padlet (www.padlet.com). Padlet may be described as an online wall, which allows contributors to share their thoughts on what works somewhat like a virtual piece of paper. On advice from the participating schools, Padlet would be acceptable to parents' frequent concern about the internet and child safety (Newman and Oates, 2014). 
Hackley (2003) claims the value of having consumer insights frame and direct creative work to be well established. Whilst this practice is common within the advertising industry, few academic studies report on this aspect. Bartholomew and O'Donohue (2003) describe a research initiative using focus groups, where children provided verbal suggestions for advertising strategies for an imaginary soft drink. In this research study, the participants produced a range of poster- and film-style advertisements. A worksheet was provided to guide the design work. Figure 8 provides an overview of the three research stages. 

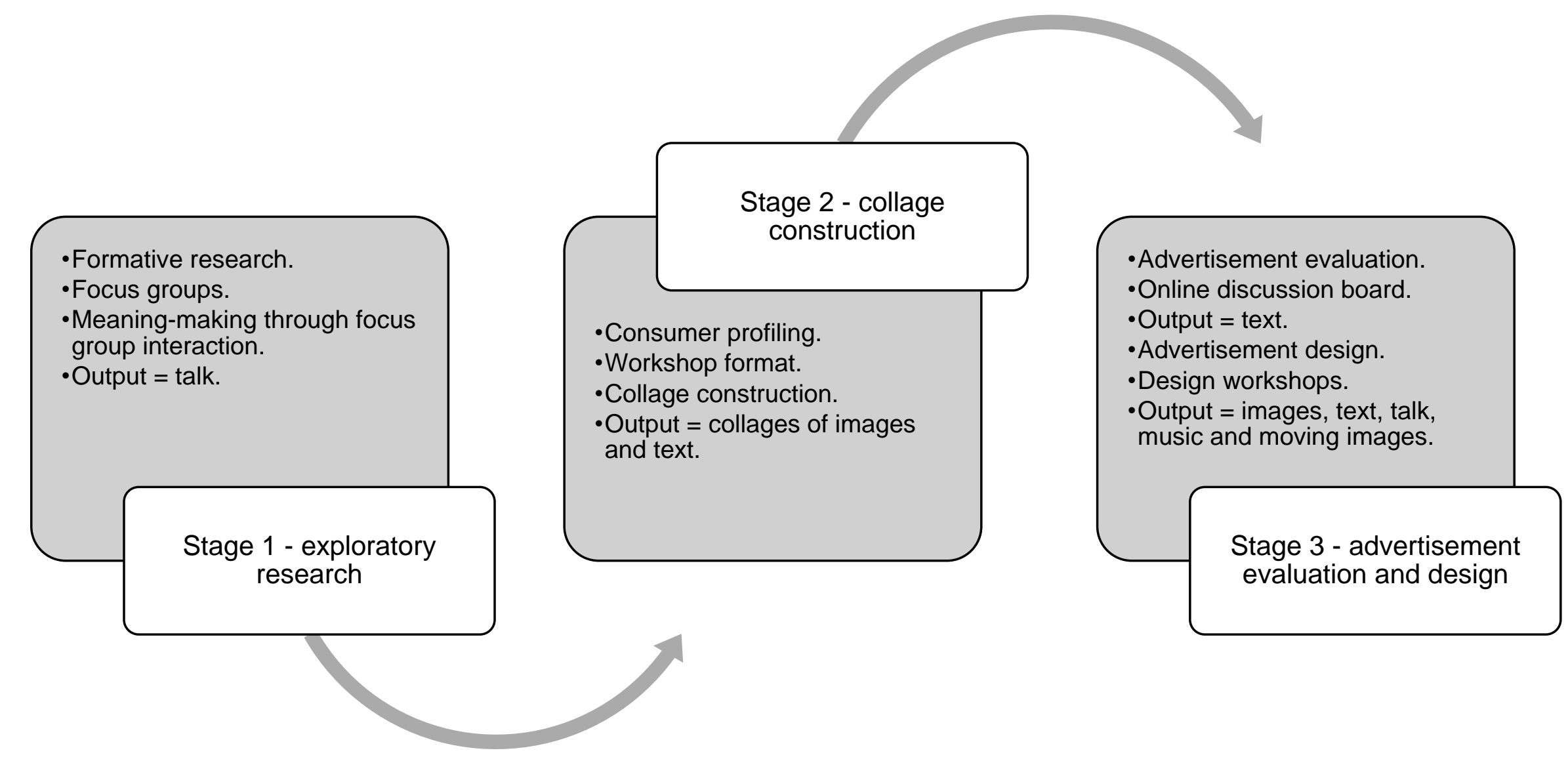

Figure 8: The three stages of the research study. 


\section{Representing the voices of young consumers}

Hackley (2001) argues that social texts (for this research study: focus group transcriptions, collages, Padlets and participants' advertisements) are open to differing interpretation and recommends the use of discourse analysis within a social constructionist ontology. Simunaniemi et al. (2012) recognise that people gain knowledge in social communication and maintain that perceptions of healthy eating represent "a product of social practices in which language plays a central role" (p. 67). Essentially, in a social constructionist spirit, discourse analysis entails a focus on the use of language in context. Bucknall (2014, p. 72) maintains that 'voice' is not an autonomous, but a social production, requiring communication to be recognised as a local, interactional activity. Alldred and Burman's (2005) notion of discourse similarly points to the importance of context. Consequently, accounts that young consumers give researchers need contextualising by explicit reference to the social context. Further, context in a physical sense may impact on the researcher-researched relationship. As previously recognised, the predisposition of schools to reinforce adultchild power (Westcott and Littleton, 2005; Kellett, 2010) must be recognised.

A widely used general process of interpretation is that of the hermeneutic circle, a concept based on the idea that in order to understand the part (e.g. a detail of discursive practice), the interpreter needs to apprehend the whole (e.g. transcripts of focus group talk, relevant cultural discourses, the discursive context). The process of interpretation proceeds through a series of back-and-forth, part-to-whole iterations. The goal of hermeneutic interpretation is to produce different interpretations in order to bring about change. The researcher should challenge the obvious and provide new ways of interpreting the world (Moisander and Valtonen, 2006). This process, however, is circular and never ending, as we continuously re-evaluate and revise our understanding of the social world (Clarke, 2006).

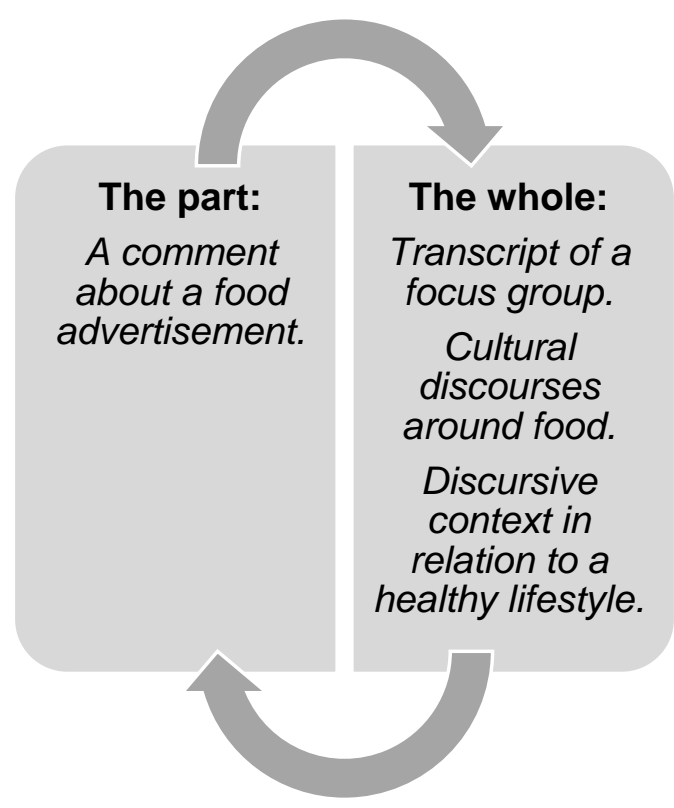

Figure 9: The adoption of a hermeneutic approach to data analysis. 
The fieldwork produced verbal and visual data. Hearn and Thomson (2014) recognise that images can be counted and categorised, but also seen as discourse and narrative. Scott (1994, p. 264) proposes that advertising images may be understood as a "discursive form" much like writing and capable of delivering subtle nuances in communications. Moisander and Valtonen (2006) recommend that visual images be analysed as texts, based on a particular visual vocabulary and a visual grammar. Hence, the analysis proceeded hermeneutically (see figure 9), paying close attention to verbal and visual aspects.

The following sections briefly account for the method of data analysis used in each stage (see figure 10 for an overview).

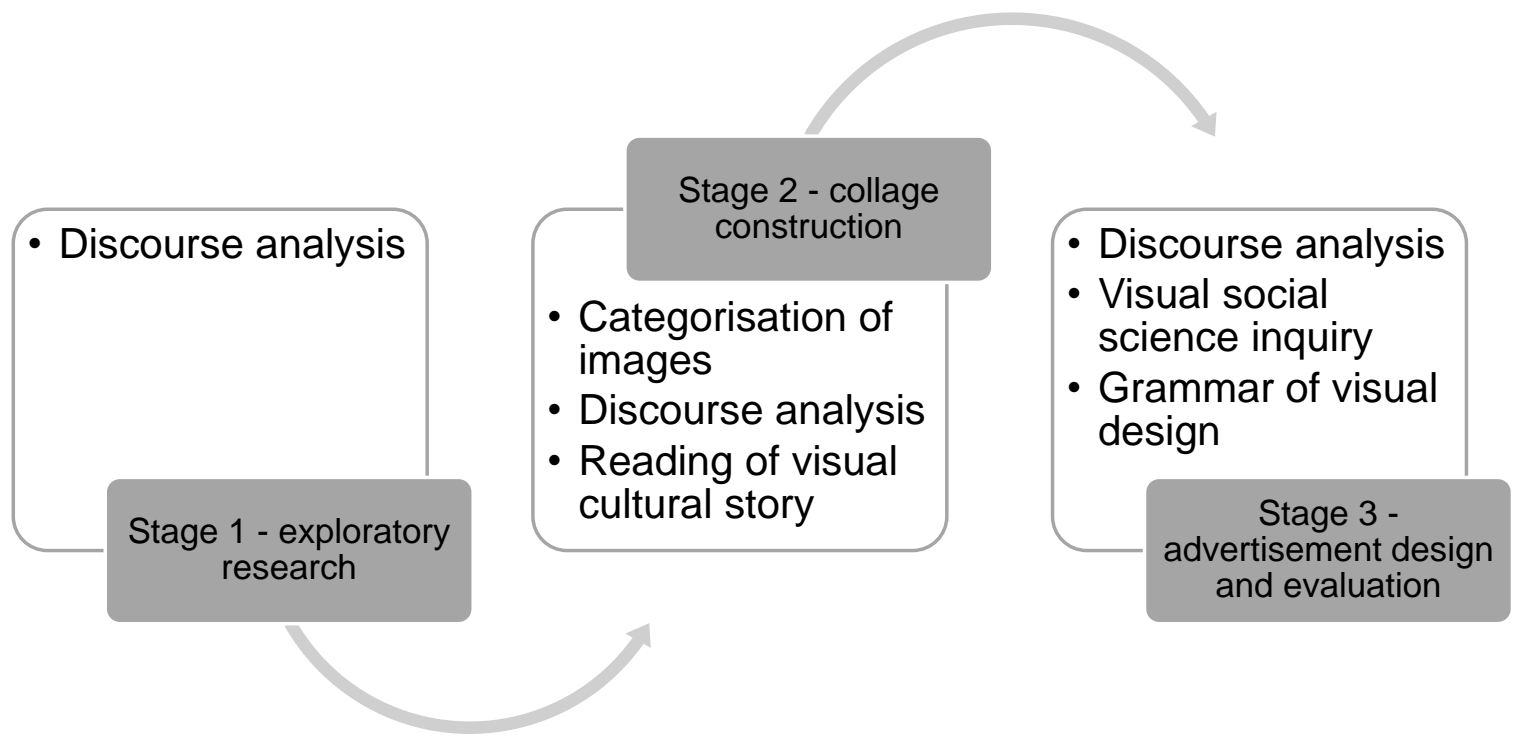

Figure 10: Approaches to data analysis.

\section{Analysis of stage 1 - the exploratory research}

The data collected during this stage was 'talk', which was analysed using discourse analysis (Brown and Yule, 1983; Paltridge, 2012). Hence, the transcribed text was read closely in order to identify dominant themes, which in turn were analysed in order to establish discourses or particular ways of talking about healthy eating and aspects of food advertising. Fairclough (2003) proposes that a discourse is a particular way of representing some part of the social world, with alternative discourses associated with different groups of people. Establishing discourses central to food and food advertising among young consumers was seen as essential in order to inform the promotion of healthy foods to the age group. 
Analysis of stage 2 - the consumer collages

The analysis followed the overall guidance of Pachler (2014) of using a hermeneutic interpretation procedure (see figure 9). Accordingly, in the analysis used, 'parts' referred to single elements in the collages (images and words), whereas the 'whole' referred to the collages in their entirety and the context in which they were constructed. The first stage of the analysis used categorisation, essentially mapping the 'parts'. Units of data - images and words - were classified as representing a more general category (Spiggle, 1994), each of which received a label. The visual images were not analysed in their own right, but allowed a means for the participants to communicate aspects of their lives, experiences and identities (Emmison et al., 2012). As such, the collages were seen to represent visual language to be read as a visual cultural story (Moisander and Valtonen, 2006). The emerging themes - verbal and visual - were analysed using discourse analysis (Brown and Yule, 1983; Paltridge, 2012). This analysis took place within the socially constructionist perspective of the distributed self, important assumptions of which are that the self is continuously shaped and re-shaped through interactions with others and that language, talk and discourse provide raw materials for the construction of the self (Wetherell and Maybin, 1996).

Equipped with the collage labels ('parts') and the audio-recordings of the collage construction workshops, including the participants' verbal summaries of the 'typical consumers' delivered at the end (part of 'the whole'), the researcher wrote 'narrated vignettes' of twelve named (the participants gave each of their consumers a name), 'typical 13-year-old consumers' emerging from the data. This process was informed by insight picked up during the stage 1 focus groups (another part of 'the whole'). The vignettes, in their position as "empirically sourced narratives", described socially constructed consumers as portrayed in the collages and spoken about by the research participants. The purpose was for the collages and narrated vignettes combined to bring the consumers to life (Quinn and Patterson, 2013, p. 730).

Analysis of stage 3 - the advertisement evaluation and the participant-designed advertisements

The analysis of the Padlets used a format similar to that described by Simunaniemi et al. (2012) in their analysis of discourses in a sample of fruit and vegetable-related weblog texts. Accordingly, the analysis began by reading the postings on the discussion wall with an open mind in order to identify recurrent patterns in the data. A number of preliminary themes were identified and coded into thematic categories. Following further reading of the postings, in the second phase the preliminary themes were crystallised into themes. In the third stage, the themes were categorised into a range of main discourses.

The advertisements designed by the research participants varied in their type of presentation from poster advertisements to simple films. Accordingly, the analysis employed discourse analysis (Brown and Yule, 1983; Paltridge, 2012) for the verbal elements. The images contained in the advertisements were thought of as like language' and were 'read' in order to interpret their meaning in a similar way to the 
advertising copy (Hall, 1997, p. 5). In common with Emmison et al.'s (2012, p. 113) principles, the analysis looked for "manifest themes" across images, whilst simultaneously exploring the social aspects displayed. The analysis then used aspects of Emmison et al.'s (2012) approach to visual social science inquiry. Accordingly, the visual data were approached "sociologically" with the aim of investigating how the data may serve as "sources of concrete visual information about the abstract concepts and processes which are central to organising everyday social life" (p. 63).

The analysis also employed Kress and van Leeuwen's (2006) grammar of visual design, a particular approach to visual semiotics, where the visual representation is set within the theoretical framework of social semiotics. In social semiotics, the focus is upon sign-making (rather than the use of ready-made signs). Kress and van Leeuwen's visual grammar concentrates on the way in which visual elements combine in visual statements into meaningful wholes, with attention paid to representational, interactive and compositional patterns. The resulting visual structures refer to particular interpretations of experience and forms of social interaction.

\section{The value of longitudinal research}

There were particular reasons for this research study's use of a longitudinal perspective. First and foremost, the objectives were ambitious and could not have been fulfilled within one fieldwork session alone. Spacing the research out over a longer time period enabled the adoption of gradually more challenging research techniques. What is more, it allowed appreciation of the participants' development of market persuasion knowledge (Wright et al., 2005; Saunders et al., 2016). Importantly, the longer-term perspective meant that the research study could evolve over time, with the possibility of adaptations to changing circumstances.

There are, however, challenges associated with longitudinal research. Accordingly, the recruitment process was more challenging with the field sites having to commit to research taking place over a three-year period. Ongoing relationship maintenance was needed to ensure co-operation of the schools. Parental and participant consent had to be sought for each event. Some attrition followed with a small number of participants deciding not to take part in subsequent stages. Overall, the research study required substantial time and financial investment. The advantages and challenges of a longitudinal approach as perceived from this research study are summarised in table 1. 


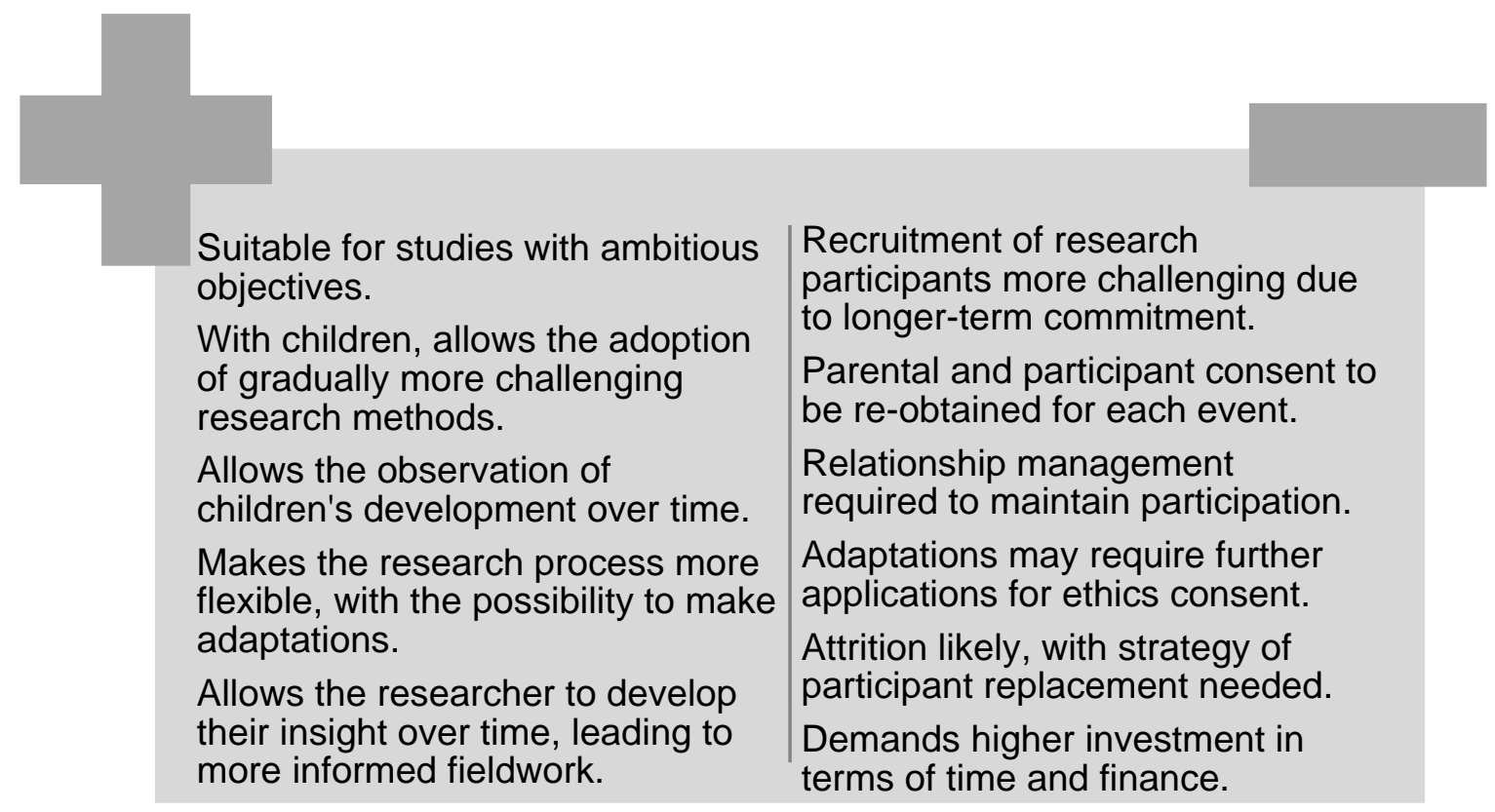

Table 1: The advantages and challenges of longitudinal research with young consumers.

\section{Conclusion: Amplifying the voices of young consumers}

This chapter has reported on a research study with young consumers, where the research methodology decisions were driven by the quest to give voice to this consumer group. The adoption of a social constructionist perspective, which sees meaning and reality as discursive constructions in social interaction, turned the focus upon language (Hackley, 1998; Moisander and Valtonen, 2006). This final section will highlight the main methodological insights gained during this research study, both in terms of successes and points of learning. Recommendations for future research approaches of a qualitative nature within the domain of food advertising will be provided, aspects of which may be transferred to other areas of relevance to young consumers.

In terms of amplifying the voices of the young consumers, this was achieved by conducting the research from their perspective and through careful consideration of how to facilitate their expression. Altogether, the various stages of the research study - focus group discussions, collage construction, Padlet discussions and advertisement design - allowed the young consumers to express their voice in a variety of languages - verbally, visually and in text - in a manner that allowed factual, emotional and creative expression of their opinions, feelings and ideas. The resulting fieldwork data could then be analysed by means of discourse analysis for talk, text and copy and more specialist methods for visual elements, music and movement.

The exploratory focus groups provided access to a wealth of discourses around healthy eating and food advertising. The 'typical consumers' in the collages provided deep insight of a kind denied to a positivist research orientation. The collages in 
combination with the narrated vignettes helped to bring the socially constructed consumers alive. By virtue of a longitudinal design, more demanding research activities could be introduced over time. In the final stage of the research study, Padlet provided yet another mouthpiece for the young consumers to express their own voice and so effectively provided access to their discourses around advertisements promoting healthy eating/living. What is more, the young consumers expressed their creative ideas in complete creative concepts that resulted in poster-style and film advertisements.

The research methods literature highlights the risk of a power differential between young participants and a research team. However, this research study saw the young consumers as "competent research participants" (Sparrman, 2009, p. 299), who in their position as "co-creators of knowledge" (Kellett, 2014, p. 24) were gatekeepers to valuable information relating to their age group. What is more, use of a group context is likely to have made them collectively powerful (Smithson, 2000). Additionally, the use of visual materials in the collage construction and the advertisement design may have facilitated further reduction of any power differential (Emmison et al., 2012).

The research process resulted in points of learning that provide opportunities for future research. Accordingly, the narrated vignettes were authored by the researcher and so, unlike all the other data, did not represent the first-hand voice of the young consumers. Future studies could task young consumers with writing consumer stories around typical consumers their own age. Further, despite their richness and illuminating variety, the collages still represented mosaics of visual and verbal snippets, a snapshot at a point in time. Whilst still recruiting through school, future research could take the fieldwork away from the school environment and accompany young consumers to various consumption contexts, such as a visit to a fast food restaurant. This ethnographic approach would allow the researcher to tap into young consumers' discourse around fast food in a social context, enabling exploration of aspects of marketing communication in situ. It would also assist in getting round the precise timeallocation frequently allocated to research by schools (e.g. Verhellen et al., 2014), a by-product of their main priority of achieving of academic benchmarks.

Whilst the research design described in this chapter did assist in amplifying the voices of the young consumers, there are ways in which research may strengthen the impact of their voices. One approach is simply to continue to conduct research with young consumers, from their perspective. The academic community is in a powerful position to conduct research with young consumers that is inclusive of the group. Recognising as a responsibility the need to conduct research that is accessible to young consumers, may enable and empower them to contribute towards a critical, societywide conversation around issues such as childhood obesity and the role of food advertising. Such research would benefit further from a cross-national perspective. Platforms such as Padlet offers safe and inexpensive platforms for conducting such research, with the online environment in a position to amplify their voices and spread the conversation further and wider. 


\section{References}

Alderson, P. (2014). Ethics. Pp. 85-102 in Clark, A., Flewitt, R., Hammersley, M. and Robb, M. (Eds.). Understanding Research with Children and Young People. London: SAGE Publications Ltd.

Alldred, P. and Burman, E. (2005). Analysing children's accounts using discourse analysis. Pp. 175-198 in Greene, S. and Hogan, D. (Eds.). Researching Children's Experience. Approaches and Methods. London: SAGE Publications Ltd.

Banister, E. N. and Booth, G. J. (2005). Exploring innovative methodologies for childcentric consumer research. Qualitative Market Research: An International Journal, 8 (2), pp. 157-175.

Bartholomew, A. and O'Donohue, S. (2003). Everything under control: A child's eye view of advertising. Journal of Marketing Management, 19 (3-4), pp. 433-457.

Belk, R. W., Ger, G. and Askegaard, S. (2003). The fire of desire: A multisited inquiry into consumer passion. Journal of Consumer Research, 30 (3), pp. 326-351.

Berger, P. L. and Luckmann, T. (1967). The Social Construction of Reality: A Treatise in the Sociology of Knowledge. Harmondsworth: Penguin.

Brown, G. and Yule, G. (1983). Discourse Analysis. Cambridge: Cambridge University Press.

Bucknall, S. (2014). Doing qualitative research with children and young people. Pp. 69-84 in Clark, A., Flewitt, R., Hammersley, M. and Robb, M. (Eds.). Understanding Research with Children and Young People. London: SAGE Publications Ltd.

Cairns, G., Angus, K., Hastings, G. and Caraher, M. (2013). Systematic reviews of the evidence on the nature, extent and effects of food marketing to children. A retrospective summary. Appetite, 62 (1), pp. 209-215.

Chan, K., Prendergast, G., Grønhøj, A. and Bech-Larsen, T. (2009). Adolescents' perceptions of healthy eating and communication about healthy eating. Health Education, 109 (6), pp. 474-490.

Chan, K. and Tsang, L. (2011). Promote healthy eating among adolescents: A Hong Kong study. Journal of Consumer Marketing, 28 (5), pp. 354-362.

Cherrier, H. (2012). Using projective techniques to consider the societal dimension of healthy practices: An exploratory study. Health Marketing Quarterly, 29 (1), pp. 82-95.

Christensen, P. and Prout, A. (2005). Anthropological and sociological perspectives on the study of children. Pp. 42-60 in Greene, S. and Hogan, D. (Eds.). Researching Children's Experience. Approaches and Methods. London: SAGE Publications Ltd.

Clarke, S. (2006). From Enlightenment to Risk: Social Theory and Contemporary Society. Basingstoke: Palgrave Macmillan. 
Davis, T. (2010). Methodological and design issues in research with children. Pp. 6178 in Marshall, D. (Ed.). Understanding Children as Consumers. London: SAGE Publications Ltd.

de la Ville, V.-I. and Tartas, V. (2010). Developing as consumers. Pp. 23-40 in Marshall, D. (Ed.). Understanding Children as Consumers. London: SAGE Publications Ltd.

Disclosure and Barring Service (no date). Disclosure and Barring Service: About us. Available at: https://www.gov.uk/government/organisations/disclosure-and-barringservice/about (accessed 23 October 2016).

Emmison, M., Smith, P. and Mayall, M. (2012). Researching the Visual. Second Edition. London: SAGE International Ltd.

ESOMAR (1999).ESOMAR World Research Codes and Guidelines. Interviewing Children and Young People. Available at: https://www.esomar.org/uploads/public/knowledge-and-standards/codes-andguidelines/ESOMAR Codes-and-Guidelines Interviewing-Children-and-YoungPeople.pdf (accessed 23 October 2016).

ESOMAR (2016). Homepage: About ESOMAR. Available at: https://www.esomar.org/about-esomar.php (accessed 23 October 2016).

Fairclough, N. (2003). Analysing Discourse. Textual Analysis for Social Research. London: Routledge.

Fraser, S., Flewitt, R. and Hammersley, M. (2014). What is research with children and young people? Pp. 34-50 in Clark, A., Flewitt, R., Hammersley, M. and Robb, M. (Eds.). Understanding Research with Children and Young People. London: SAGE Publications Ltd.

Hackley, C. (1998). Social constructionism and research in marketing and advertising. Qualitative Market Research: An International Journal, 1 (3), pp. 125-131.

Hackley, C. (2001). Marketing and Social Construction. Exploring the Rhetorics of Managed Consumption. London: Routledge.

Hackley, C. (2003). How divergent beliefs cause account team conflict. International Journal of Advertising, 22 (3), pp. 313-331.

Hall, S. (1997). Introduction. Pp. 1-11 in Hall, S. (Ed.) Representation: Cultural Representations and Signifying Practices. London: SAGE Publications Ltd.

Hastings, G. and Domegan, C. (2014). Social Marketing. From Tunes to Symphonies. Second Edition. London: Routledge.

Havlena, W. J. and Holak, S. L. (1996). Exploring nostalgia imagery through the use of consumer collages. Advances in Consumer Research, 23 (1), pp. 35-42.

Hearn, H. and Thomson, P. (2014). Working with texts, images and artefacts. Pp. 154168 in Clark, A., Flewitt, R., Hammersley, M. and Robb, M. (Eds.). Understanding Research with Children and Young People. London: SAGE Publications Ltd. 
Heath, S., Brooks, R., Cleaver, E. and Ireland, E. (2009). Researching Young People's Lives. London: SAGE Publications Ltd.

Hennessy, E. and Heary, C. (2005). Exploring children's views through focus groups. Pp. 236-252 in in Greene, S. and Hogan, D. (Eds.). Researching Children's Experience. Approaches and Methods. London: SAGE Publications Ltd.

Hill, M. (2005). Ethical considerations in researching children's experiences. Pp. 6186 in Greene, S. and Hogan, D. (Eds.). Researching Children's Experience. Approaches and Methods. London: SAGE Publications Ltd.

James, A., Jenks, C. and Prout, A. (1998). Theorizing Childhood. Cambridge: Polity Press.

Kellett, M. (2010). Rethinking Children and Research. Attitudes in Contemporary Society. London: Continuum.

Kellett, M. (2014). Images of childhood and their influence on research. Pp. 15-33 in Clark, A., Flewitt, R., Hammersley, M. and Robb, M. (Eds.). Understanding Research with Children and Young People. London: SAGE Publications Ltd.

Kress, G. R. and van Leeuwen, T. (2006). Reading Images. The Grammar of Visual Design. London: Routledge.

Lunt, P. and Livingstone, S. (1996). Rethinking the focus group in media and communications research. Journal of Communication, 46 (2), pp. 79-98.

Market Research Society (2014). The Market Research Society Code of Conduct. 1 September $2014 . \quad$ Available at: https://www.mrs.org.uk/pdf/mrs\%20code\%20of\%20conduct\%202014.pdf (accessed 23 October 2016).

Market Research Society (2016). Homepage: About MRS. Available at: https://www.mrs.org.uk/mrs/aboutmrs (accessed 23 October 2016).

Martin, M. C. and Peters, C. O. (2005). Exploring adolescent girls' identification of beauty types through consumer collages. Journal of Fashion Marketing and Management, 9 (4), pp. 391-406.

McNeal, J. U. (1992). Kids as Customers. A Handbook of Marketing to Children. New York: Lexington Books.

Mehta, K., Coveney, J., Ward, P., Magarey, A., Spurrier, N. and Udell, T. (2010). Australian children's views about food advertising on television. Appetite, 55 (1), pp. 49-55.

Moisander, J. and Valtonen, A. (2006). Qualitative Marketing Research: A Cultural Approach. London: SAGE Publications Ltd.

Newman, N. and Oates, C. J. (2014). Parental mediation of food marketing communications aimed at children. International Journal of Advertising, 33 (3), pp. 579-598. 
Oates, C. (2000). The Use of Focus Groups in Social Science Research. Pp. 186-195 in Burton, D. (Ed.). Research Training for Social Scientists. London: Sage Publications Ltd.

O'Donohoe, S. and Tynan, C. (1998). Beyond sophistication: Dimensions of advertising literacy. International Journal of Advertising, 17 (4), pp. 467-482.

Pachler, P. (2014). How Collages Reveal Your Deepest Thoughts. Hamburg: Anchor Academic Publishing.

Paltridge, B. (2012). Discourse Analysis. London: Bloomsbury Publishing Plc.

Pettersson, A. and Fjellström, C. (2006). Responsible marketing to children and their families. Young Consumers, 7 (4), pp. 13-18.

Prout, A. and James, A. (1997). A new paradigm for the sociology of childhood? Provenance, Promise and Problems. Pp. 7-33 in James, A. and Prout, A. (Eds.). Constructing and Reconstructing Childhood. Contemporary Issues in the Sociological Study of Childhood. Second Edition. London: Routledge.

Puchta, C. and Potter, J. (2004). Focus Group Practice. London: SAGE Publications Ltd.

Quinn, L. and Patterson, A. (2013). Storying marketing research: The twisted tale of a consumer profiled. Journal of Marketing Management, 29 (5-6), pp. 720-733.

Moisander, J. and Valtonen, A. (2006). Qualitative Marketing Research: A Cultural Approach. London: SAGE Publications Ltd.

Roedder John, D. (1999). Consumer socialization of children: A retrospective look at twenty-five years of research. Journal of Consumer Research, 26 (3), pp. 183-213.

Saunders, M., Lewis, P. and Thornhill, A. (2016). Research Methods for Business Students. Seventh Edition. [online]. Pearson Education Limited. Available at:<http://www.myilibrary.com?!D=819487> (accessed 5 November 2016).

Scott, L. M. (1994). Images in advertising: The need for a theory of visual rhetoric. Journal of Consumer Research, 21 (2), pp. 252-273.

Siemieniako, D. and Kubacki, K. (2013). Female students' drinking seen through collages and diaries. Qualitative Market Research: An International Journal, 16 (3), pp. 296-314.

Smithson, J. (2000). Using and analysing focus groups: Limitations and possibilities. International Journal of Social Research Methodology, 3 (2), pp. 103-119.

Sparrman, A. (2009). Ambiguities and paradoxes in children's talk about marketing breakfast cereals with toys. Young Consumers, 10 (4), pp. 297-313.

Spiggle, S. (1994). Analysis and interpretation of qualitative data in consumer research. Journal of Consumer Research, 21 (3), pp. 491-503.

Tonkiss, F. (2004). Using focus groups. Pp. 193-206 in Seale, C. (Ed.). Researching Society and Culture. Second Edition. London: Sage Publications Ltd. 
UNICEF (1989). United Nations Convention on the Rights of the Child. Available at: $\begin{array}{lll}\text { http://www.ohchr.org/EN/Professionallnterest/Pages/CRC.aspx } & \text { (accessed } & 17\end{array}$ October 2016).

UNICEF (2014) The State of the World's Children 2015: Executive Summary. Reimagine the Future. Innovation for Every Child. Available at: http://www.unicef.org/publications/files/SOWC 2015 Summary and Tables.pdf (accessed 17 October 2016).

Verhellen, Y., Oates, C., De Pelsmacker, P. and Dens, N. (2014). Children's responses to traditional versus hybrid advertising formats: The moderating role of persuasion knowledge. Journal of Consumer Policy, 37 (2), pp. 235-255.

Westcott, H. L. and Littleton, K. S. (2005). Exploring meaning in interviews with children. Pp. 141-157 in Greene, S. and Hogan, D. (Eds.). Researching Children's Experience. Approaches and Methods. London: SAGE Publications Ltd.

Wetherell, M. and Maybin, J. (1996). The distributed self: a social constructionist perspective. Pp. 219-280 in Stevens, R. (Ed.). Understanding the Self. London: SAGE Publications Ltd.

WHO (World Health Organization) (2016). Report of the Commission on the Ending of Childhood Obesity. Available at: http://apps.who.int/iris/bitstream/10665/204176/1/9789241510066 eng.pdf (accessed 17 October 2016).

Wright, P., Friestad, M. and Boush, D. M. (2005). The development of marketplace persuasion knowledge in children, adolescents, and young adults. Journal of Public Policy \& Marketing, 24 (2), pp. 222-233.

Young, B. (2003). Does food advertising make children obese? Young Consumers, 4 (3), pp. 19-26.

Zaltman, G. and Coulter, R. H. (1995). Seeing the voice of the customer: Metaphorbased advertising research. Journal of Advertising Research, 35 (4), pp. 35-51. 